UDC 811'276.16 (09): 811'36

DOI https://doi.org/10.32838/2710-4656/2021.4-2/02

Bolotnikova A. P.

National University "Yuri Kondratyuk Poltava Polytechnic"

Talovyria H. M.

Chernyshov $V . V$.

National University "Yuri Kondratyuk Poltava Polytechnic"

\title{
POLITENESS AS A LANGUAGE CATEGORY
}

The article analyzes politeness as a complex system of communication strategies aimed at achieving harmonious, effective and conflict-free communication, which is a regulator of communicative behavior of interactants. These strategies determine the choice of means of verbal and nonverbal communication. As a result of clearly defined methods and techniques of object cognition in terms of the theory of linguistic communication and pragmalinguistics, an attempt to describe politeness as a linguistic category based on the structure of the communicative act is made. Attention to the scientific research, which serves as a conceptual basis for a comprehensive, thorough study of the linguistic manifestation of courtesy and features of implementation of its strategies, is paid. It is proved that the use of verbal means of expressing politeness is determined by the pragmatic parameters: who speaks, to whom, for what purpose, how, under what conditions and with what effect. Therefore, the characteristics of communicators, their intentions, verbalization of communicative strategies and tactics, scope and perlocutionary effect are relevant for the analysis of language indicators functioning. Taking into account the communicative and situational aspects, the grammatical indicators of courtesy, which are based on the strategies of positive and negative politeness: morphological category of vocative and dative cases, category of personality, interstitial category of person, morphological verb categories of tense, method and type and syntactical categories of predicative denial and questioning, are distinguished. It is stated that politeness as a language category is characterized by national and cultural specificity, which is implemented not only by the formulas of language etiquette, but by strategies and tactics of influence, their verbalization, which exist in a particular communicative culture and which regulate interaction. It is emphasized that all verbal and non-verbal language units are aimed at achieving effective communication. The article describes of a successful communicative process management with the help of language indicators of the category of politeness, which characterizes it as a pragmatic strategy, aimed at influencing the intellectual, volition and emotional spheres of the addressee.

Key words: politeness, category of politeness, communicative act, language indicators, communication strategies, communicative tactics.

Statement of the problem in general and its connection with important scientific tasks. The level of polite communication often affects the behavior of interlocutors more than the substantive content of speech. The purpose of polite behavior is to convince the partner of a positive attitude towards him and cause the same feedback. At a personal level, a feedback should be personal, at a social level it ought to be formal. N. Formanovska postulates: "politeness is an ethical category, abstracted from specific people, which is reflected in the language, which, for linguistics of course, is worth studying" [1, p. 77].

Analysis of recent research and publications that have laid foundation to solutions to the problem. Communication as a type of human activity is included in social relations. When choosing the language of polite communication, an addresser takes into account the rules and norms of communication culture, i.e. a design of polite speech develops in accordance with ethical norms that govern the speech behavior of a particular linguistic and cultural community speakers. A thorough and accurate scientific description of a particular language does not do without grammatical and lexical rules concerning the differentiation of interlocutors in terms of their social status, gender and age. Clarifying the role of these rules in the general description of language represents a complex linguistic problem. 
Courtesy as a language category has repeatedly attracted the attention of researchers [2-4 and others]. Linguistic description of politeness is a component of all aspects of its research, although the behavioral approach remains dominant until these days. Most scholars consider politeness as a demonstration of respect for the addressee by the speaker, politeness is considered to be a moral quality of communicators who adhere to the external manifestations of respectful communication (formal courtesy) and internal (friendliness, kindness, sincerity) $[5 ; 6 ; 7 ; 8]$. N. Zhuravlyova emphasizes that "the combination of external and internal displays allows language politeness to be an important regulator of communication" [8, p. 9].

Linguistic politeness is important in terms of pragmatics and grammar of any language, because it is one of the central categories of linguistic pragmatics, which demonstrates the relationship between communicative partners. Politeness is implied when, in the process of stylistic variation, preference is given to a statement that takes an addressee into account more and represents respect for him. This concept is defined by the following main parameters: social nature, interlocutors' competence, compliance with the rules of the game, insincerity and verbalization [8, p. 33-34].

The representation of politeness in the Ukrainian language is of particular interest, because it almost does not consider the possibility of social relations representation between communicators with grammatical means, and if indicated, then, in fragments $[8 ; 9 ; 10 ; 11$ and others]. The lack of study of theoretical and practical issues of verbal means of expressing politeness in the Ukrainian language studies indicates the need for their refinement.

Extraction of previously unsolved parts of the general problem to which this article is devoted. A researcher of a courtesy category $\mathrm{R}$. Gushcha notes that before describing language politeness it is important to remember that this phenomenon cannot be considered in terms of three traditionally accepted branches of semiotics, since semantics studies the connections between language signs and reality, syntactics describes the connection between signs themselves, and pragmatics studies the connections between language signs and native speakers, thus, politeness, the meaning of which is to demonstrate the relationship between participants of interaction, does not belong to any of these fields [12, p. 47]. Linguistic politeness should be analyzed as a component of an utterance meaning, which is influenced by a communicative situation (connection with semantics and pragmatics) and which is realized by means of language (connection with the grammatical system of a language). Language politeness, N. Zhuravlyova emphasizes, "It is the art to express the inner respect we feel for another person by external signs" [13, p. 7].

Therefore, politeness is considered as a language category, the content plan of which is determined by the semantic components of polite communication (respect, friendliness, parity), and the plan of expression is delivered by communicative strategies and tactics implemented by language tools that affect communication effectiveness. It is also important for our study to answer the question: how a clearly defined communicative intention can be realized with the help of language units.

Formulation of the article goals (task statement). The purpose of the article is to analyze the approaches to the communicative-pragmatic category of politeness in the scientific literature, as well as the specifics of linguistic representation of the category of politeness.

Distinguishing of the main features of the study with a full proof of the obtained scientific results. Politeness is aimed at the appropriate use of language indicators and adherence to strategies and tactics of communicative behavior, traditions, rules and norms of a particular ethnic group in order to successfully communicate. O. Zemska classifies politeness to implicit categories of communicativepragmatic nature, which represents itself at different levels of language [14]. That is, it is not only about stable, repetitive, routine formulas, but broader phenomena, which we qualify as indicators. The term indicator (from the Latin indicator - index), borrowed from the natural sciences, was introduced into pragmalinguistics by J. Austin, and developed and supplemented by J. Searle. It is used to denote verbal and nonverbal means that demonstrate certain linguistic phenomena, primarily functional. O. Pocheptsov notes that the rules of a language functioning unit as an indicator are determined by the following features of the illocutionary act: a) an illocutionary act is carried out by a speaker; b) anillocutionary act is realized during an act of speech; c) an illocutionary act affects the addressee of speech, as it has a certain intention and communicative orientation [15, p. 37]. By indicator we mean those linguistic means (lexical, grammatical) with which a speaker, manipulating the sphere of rational and emotional, implements strategies of positive and negative politeness to achieve a communicative goal. In the process of communication, they perform 
a regulatory function, designed to manifest politeness and influence an emotional and volition sphere of a man.

Indicators of politeness, which demonstrate a social and psychological distance of communicators, as well as realize a communicative intention of interlocutors, are widely presented in the Ukrainian language. V. Shinkaruk and M. Teleky note that courtesy in the Ukrainian language studies is "represented by language means of different levels: 1) communicative-semantic groups - intentional expressions, communication stereotypes that reflect nationally specific manifestations of politeness; 2) morphological (modal and pronoun words, predicates, conjunctions, particles, exclamations, forms of a person, a number, tense, manner, type of verbs); 3) syntactic (allocution, sentence constructions of different types); 4) wordbuilding (formations with diminutively hypocoristic suffixes); 5) phonetically graphic (intonation, author's punctuation marks); 6) stylistic (emotionally expressive and subjectively evaluative components of words and sentences meanings)" [16, p. 113].

A system of language indicators that demonstrate relationships between people is implemented in the Ukrainian language at all levels and distinguishes grammatical, lexical and stylistic means. This distinction is complicated by their close connection, when the semantics of a word may impose restrictions on the use of grammatical forms, while grammatical categories, in its turn, affect the actual choice of lexical means. To construct a stylistically correct statement, it is necessary to coordinate grammatical and lexical indicators of politeness. In the process of communication, interlocutors hardly notice language indicators when they are present, but immediately notice their absence, because they feel discomfort in contact. Proper performative specificity of polite speech behavior requires describing grammatical indicators in the categories of linguopragmatics, analyzing and comparing means which actualize illocutionary power of utterances.

Modern linguistics is characterized by increased attention to the field approach in the study of language categories. G. Shamienova emphasizes that "politeness is structured and can be represented in the form of a communicative-pragmatic field" [17, p. 5]. The researcher understands the communicative-pragmatic field of politeness as the unity of content, tactical planning and form. The field of politeness is organized by the interaction of language tools of different levels (lexical, wordbuilding, morphological, syntactic), in particular, special actualizers of politeness, established communication formulas, clichéd constructions that promote the expression of politeness [17, p. 9]. O. Bondarko emphasized the importance of studying the functional-semantic field of politeness, noting that "it is necessary to pay attention to such nontraditional (for the study of Indo-European languages) aspects of functional-grammatical description, as an expression of courtesy. The connections of politeness expression with grammatical categories (in particular, a person, a number, a method) are obvious, although this phenomenon differs from the described functional-semantic fields by the pragmatic nature of functions" [18, p. 44]. N. Formanovska, studying language etiquette and its relation to the functional-semantic field of politeness as a systemic semantic association, concludes that language etiquette as a sum of situational-thematic associations of communicative units that function to establish, maintain and finish speech contact with an interlocutor, and the structural-forming complex belongs to the functional-semantic field of politeness, the core of which in some languages, such as Japanese, Korean, can be a grammatical category. This field of politeness intersects with the field of motivation, that in the Ukrainian language is realized in situations of singular and plural imperative forms opposition: Ciдай! - Ciдаüme!; imperative and various means of indirect speech acts registering: Допоможіть! Чи не могли б Ви мені допомогти?; sometimes perfect and imperfect form: Зачиніть вікно, будь ласка! - Зачиняйте вікно, будь ласка! On the basis of a well-formed conceptual base N. Zhuravlyova concludes that the Ukrainian epistolary politeness of the XIX - early XX centuries has a clearly defined structure. It represents a functional-semantic field, which consists of two etiquette macrofields: lexical-semantic and lexical-phraseological, which are divided into several microfields [19]. Thank to latest achievements of ethnical linguopragmatics and communication studies a successful attempt of complex analysis of diverse and factual material is made. In addition to this, it is convincingly proved that usage of language stereotypes for marking courtesy in a written discourse of famous people turns into creativity or, as a scientist says, poetry.

The realization of politeness in language is something more than the usual use of individual units in specific communicative situations, it is the construction of these situations. Courtesy, as one of the forms of national mentality demonstration, is closely related to the structure of language, it explains the behavior of a linguistic personality. Politeness is also the linguistic realization of a communicative intention 
of a speaker, planning and modeling a communicative strategy with the help of language indicators in order to achieve effective communication. The system of language tools is diverse and can be described in terms of politeness potential. Following T. Larina [20]; P. Brown, S. Levinson [21], authors believe that the basic mechanism of human relationships is based on the opposite actions performed by interlocutors in the process of interaction: approaching - distancing. Every language has a distinguished set of language indicators of different levels for expressing politeness which represent a system of oppositions, positive courtesy-negative courtesy, in particular.

The essence of politeness is to reflect a relationship between participants of communication with the help of language indicators. It is important not only to describe the constituent elements of politeness formulas meaning, but also to study the situation of their use and demonstrate a speaker's attitude to an addressee. R. Gushcha emphasizes that politeness as a category of language is closely related to $\phi$ situation of dialogue, or rather $\phi$ situation of direct communicative contact [22, p. 52], and therefore is always realized where language means indicate participants of interaction, for example, personal pronouns, interrogative and imperative forms, etc. So, the question Чи не могли б Ви зачинити вікно? is not only an act of request, in such a way a speaker demonstrates their politeness (avoids a direct request in order to preserve the negative image of a communicative partner). Under the same conditions the statement Зачиніть вікно! is an act of neutral request, the speaker does not show politeness. It is quite correct in terms of grammar, but given the pragmatic rules may be inappropriate (perceived as impolite). It often depends on the communication situation and a relationship between communicators to whom a speaker can order or simply hint, and who should be politely asked.

The use of courtesy indicators is governed by the following rules:

a) actually linguistic, which regulate the choice of lexical means, grammatical categories, syntactic constructions among functionally close or synonymous;

b) social, requiring to use language units in accordance with the social status of interlocutors;

c) situational, which demonstrate the correspondence of language indicators and communicative situation, its tone and atmosphere.

Conclusion to the study and prospects for further exploration in this direction. Thus, any language is represented by a wide repertoire of language tools that allow to demonstrate distance and implement strategies of positive and negative politeness. The research is an attempt to distinguish, analyze, describe and systematize verbal indicators of politeness, their communicative-pragmatic potential and semantic modification, which is also a prospect for the analysis of language units in the future.

\section{References:}

1. Формановская Н. Речевое взаимодействие : коммуникация и прагматика. Москва : Икар, 2007.480 c.

2. Алпатов В. Категории вежливости в современном японском. Москва : Наука, 1978. 109 с.

3. Баландіна Н. Функції і значення чеських прагматичних кліше в комунікативному контексті : монографія. Київ : АCMI, 2002. 332 с.

4. Болотнікова А. Граматичні індикатори вираження категорії ввічливості в українській мові : дис. ... канд. філол. наук: 10.02.01. Запоріжжя, 2018. 257 с.

5. Ратмайр Р. Прагматика извинения : Сравнительное исследование на материале русского языка и русской культуры. Москва : Языки славянской культуры, 2003. 272 с.

6. Шамьенова Г. Принцип вежливости как особая коммуникативно-прагматическая категория в русском речевом общении : дис. ... канд. филол. наук: 10.02.01. Саратов, 2000. 189 с.

7. Журавльова Н. Поетика української епістолярної ввічливості XIX - початку XX ст. Запоріжжя : Запорізький національний університет, 2012. 548 с.

8. Вєтрова Е. Граматичні особливості етикетних одиниць на позначення звертання в епістолярній спадщині Т. Г. Шевченка. Лінгвістичні студії : збірник наукових праць. Донецьк : Вид-во ДонДУ, 2001. Вип. 8. С. 184-192.

9. Гнатюк Л. Прагматичні й функціонально-комунікативні аспекти ввічливості (на матеріалі сучасної української мови) : автореф. дис. ... канд. філол. наук: 10.02.01. Івано-Франківськ, 2007. 18 с.

10. Телеки М. Соціальні категорії модусу в текстах епістолярного жанру. Київ : Видавництво МДГУ імені Петра Могили, 2007. 176 с.

11. Huszcza R. Honoryfikatywność. Gramatyka. Pragmatyka. Typologja. Warszawa : Wydawnictwo Naukowe PWN, 2006. $228 \mathrm{~s}$.

12. Земская Е. Категория вежливости : общие вопросы национально-культурной специфики русского языка. Zeischrift fur Slavische Philologie 56. 1997. № 2. S. 271-301. 
13. Почепцов О. Основы прагматического описания предложения. Киев : Вища школа, 1986. 116 с.

14. Телеки М. Соціальні категорії модусу в текстах епістолярного жанру. Київ : Видавництво МДГУ імені Петра Могили, 2007. 176 с.

15. Бондарко А. Принципы функциональной грамматики и вопросы аспектологии. Ленинград, 1983. $208 \mathrm{c}$.

16. Ларина Т. Категория вежливости и стиль коммуникации. Сопоставление английских и русских лингвокультурных традиций. Москва : Рукописные памятники Древней Руси, 2009. 512 с.

17. Brown P., Levinson S. Politeness : Some Universals in Language. Cambridge : Cambridge Univ. Press, 1987. $345 \mathrm{p}$.

18. Huszcza R. Honoryfikatywność. Gramatyka. Pragmatyka. Typologja / R. Huszcza. Warszawa : Wydawnictwo Naukowe PWN, 2006. 228 s.

\section{Болотнікова А. П., Таловиря Г. М., Чернишов В. В. УВІЧЛИВІСТЬ ЯК МОВНА КАТЕГОРІЯ}

У статті здійснено аналіз увічливості як складної системи комунікативних стратегій, спрямованих на досягнення гармонійного, ефективного та безконфліктного спілкування, щзо є регулятором комунікативної поведінки інтерактантів. Ці стратегї визначають вибір засобів вербальної та невербальної комунікації. Унаслідок чітко окреслених методів і прийомів пізнання об' єкта з погляду теорії мовної комунікації та прагмалінгвістики зреалізовано спробу описати увічливість як мовну категорію на основі структури комунікативного акту. Звернено увагу на наукові розвідки, щзо слугують кониептуальною базою для комплексного, трунтовного вивчення мовної маніфестації ввічливості й особливостей реалізації ї̈ стратегій. Автор доводить, щэо вживання вербальних засобів вираження ввічливості детерміноване прагматичними параметрами: хто говорить, кому, з якою метою, як саме, за яких умов та з яким ефектом? Тому релевантною для аналізу функиіювання мовних індикаторів є характеристика комунікантів, їхніх інтенцій, вербалізація комунікативних стратегій $і$ тактик, сфери вживання та перлокутивного ефекту. Беручи до уваги комунікативний та ситуативний аспекти, розрізняють граматичні показники вираження ввічливості, які засновані на стратегіях реалізачії позитивної та негативної ввічливості: морфологічна категорія кличного та давального відмінків, категорія персональності, міжчастиномовна категорія особи, морфологічні дієслівні категорії часу, способу та виду, синтаксичні категорії предикативного заперечення та питальності. Автор констатує, що ввічливість як мовна категорія характеризується національно-культурною специфікою, яка реалізується не лише формулами мовного етикету, але стратегіями і тактиками впливу, їх вербалізацією, які є в конкретній комунікативній культурі та які регулюють взаємодію. Важливо, щуо всі вербальні та невербальні мовні одинииі спрямовані на досягнення ефективності спілкування. Можна говорити про керування успішним комунікативним процесом за допомогою мовних індикаторів категорії ввічливості, щзо характеризує ї̈ як прагматичну стратегію, маючи на меті вилив на інтелектуальну, вольову й емоиійну сфери адресата.

Ключові слова: увічливість, категорія ввічливості, комунікативний акт, мовні індикатори, комунікативні стратегії, комунікативні тактики. 